\title{
Presence of organic pollutants in the São Francisco river and its compartments
}

\author{
Isabela Claret Torres ${ }^{1 *}$ \\ Adolf Heinrich Horn ${ }^{2}$ \\ 1 Department of Geography \\ Geoscience Institute \\ Federal University of Minas Gerais. \\ Av. Antônio Carlos, 6627 \\ Av. Antonio Horizonte MG Brazil \\ CEP 31207-901 \\ ${ }^{2}$ Department of Geology \\ Geoscience Institute \\ Federal University of Minas Gerais. \\ Av. Antônio Carlos, 6627 \\ Belo Horizonte MG Brazil \\ CEP 31207-901 \\ *Corresponding author \\ iclarett@hotmail.com
}

\begin{abstract}
RESUMO
A presença da poluição por compostos orgânicos é de grande preocupação ambiental. Esses tipos de compostos podem ser encontrados em diferentes habitats e possuem efeitos deletérios e de longo prazo em todas formas de vida. O principal objetivo desse estudo foi de verificar a presença de orgânicos nos diferentes compartimentos do rio São Francisco. Quatorze pontos foram coletados desde a nascente do rio até as lagoas marginais na cidade de Pirapora. O sedimento fino foi submetido a extração pelo método de Sohxlet. Os extratos foram medidos em um espectrofotômetro na faixa de absorbância de $589 \mathrm{~nm}$ que corresponde à faixa do amarelo a qual corresponde a extração dos orgânicos. A matéria orgânica dos sedimentos também foi mensurada. Houve uma correlação positiva entre o conteúdo de matéria orgânica e a absorbância na faixa do amarelo. Entretanto, não foi observada uma correlação entre o conteúdo de matéria orgânica e absorbância e a distância da nascente. Mesmo que não tenha sido possível mensurar os tipos de orgânicos presentes nos sedimentos, os resultados desse estudo claramente indicam a presença desses compostos nas amostras. A correlação da matéria orgânica com a absorbância mostrou que a primeira é um importante mecanismo de sequestro de orgânicos. Mais estudos devem ser conduzidos para determinar que tipos de compostos orgânicos estão presentes e se existe transferência destes na cadeia trófica aquática.
\end{abstract}

Palavras-chave: Rio São Francisco, sedimentos, compostos orgânicos, poluição

\section{ABSTRACT}

There has been great concern about the presence of organic pollutants in the environment. These types of compounds can be found in different types of habitats and have long term and deleterious effects on all living beings. The main objective of this study was to verify the presence of organic pollutants in different compartments of the São Francisco river. Fourteen sites were sampled from its springs till marginal lagoons in Pirapora City. The fine sediment was subjected to the Soxhlet extraction. The extracts were measured in a spectrophotometer in the absorbance range of $589 \mathrm{~nm}$, which correspond to a yellow spectrum, which corresponds to the extraction of the organic pollutants. The organic matter of the sediments was measured. There was a positive correlation between organic matter content and the absorbance in the yellow color. However, both organic matter content and absorbance did not correlate with the distance from the spring. Even though it was not possible to measure which organic pollutants were present in the sediments of the different compartments of the São Francisco river, the results of this study clear indicates the presence of these compounds in the samples. The correlation of the organic matter content and the absorbance showed that the organic matter is an important constituent in the sequestration of the organic pollutants. More studies should be conducted to determine which types of compounds are present in these sediments and if there is transfer of these organic pollutants in the aquatic food chain.

Keywords: São Francisco river, sediments, organic compounds, pollution 


\section{INTRODUCTION}

There has been great concern about the presence of organic pollutants in the environment. These types of compounds can be found in different types of habitats and have long term and deleterious effects on all living beings (HONG et al. 1995). The presence of these compounds in the environment is linked to the discharge from industrial and other human activities as agriculture (HONG et al., 1995). Once these compounds reach the aquatic environment they can be in dissolved or sorbed states (GSCHWEND; WU, 1985). In sorbed state these compounds can be adsorbed to soils particles or organic matter (GSCHWEND; WU, 1985). The dissolved form of contaminants in pore water is considered to be bioavailable, compared to the bound chemical, which does not exert direct biological effects (MEGHARAJ et al., 2011). The sequestration of organic pollutants are affected by factors such as organic matter, cation exchange capacity, micropore volume, soil texture and surface area (CHUNG; ALEXANDER, 2002).

The ecotoxicity of these compounds are mainly related to the hydrophobic characteristic of these compounds (HEITZER et al., 1992) and it has been proposed that the persistence of certain compounds in the environment is related to this hydrophobicity (CERNIGLIA, 1992). Many factors govern the behavior and fate of organic pollutants in sediments and soils, as their characteristics, compound properties, and environmental factors as temperature and precipitation (REID et al., 2000). Leaching into groundwater, biodegradation, volatilization to air, binding to soil solid phases and transfer to organisms is one of the several fates of these organic pollutants in the environment (REID et al., 2000)

Diverse types of organic pollutants occur in the environment as petroleum oil, hydrocarbons (e.g., aliphatic, aromatic, polycyclic aromatic hydrocarbons (PAHs), BTEX (benzene, toluene, ethylbenzene, and xylenes), chlorinated hydrocarbons like polychlorinated biphenyls (PCBs), trichloroethylene (TCE), and perchloroethylene, nitroaromatic compounds, organophosphorus compounds) solvents, pesticides (organophosphorus and organo-chlorine) (MEGHARAJ et al., 2011).
These organic pollutants can persist in the environment for a long time due to the fact that they are resistant to photolytic, chemical and biological degradation (BUCCINI, 2003; PARIATAMBY; KEE, 2016). Organic pollutants can be found all over the world, even in arctic region as they can travel far away from its source and present high stability (BROWN; WANIA, 2008). Due to this fact the presence of these compounds in the environment is of major concern and they present long persistence, long-range transportability, ability to accumulate in fatty tissue and are toxic at very low concentration (TANG, 2013). Besides its importance there is a lack of the studies of the presence of organic pollutants in the São Francisco watershed.

The São Francisco River drains an extensive area of the Brazilian territory, being its first springs located in the state of Minas Gerais (southeastern region of Brazil) and the river mouth in the border of the states of Sergipe and Alagoas (northeastern region). It is one of the most important rivers for the country and its basin is responsible for supplying water for a population of approximately 14.2 million $(7.5 \%$ of the Brazilian population) in a territory with different economic activities. This river is of great importance because it drains vast arid lands in Brazil, being the only source of water for the local population. The water resources of the main channel and its tributaries are used for different purposes, with emphasis on human consumption, energy production, irrigation and intense agricultural activities, disposal of wastewater from domestic and industrial activities. Therefore, the quality of its waters is of great concern, since the decrease in quality may have strong social and economic impacts.

The main objective of this study was to verify the presence of organic pollutants in different compartments of the São Francisco River. The fluvial system can be divided in different compartments, each one showing varied dynamics and resulting in different features and environments. The river channel, the inundation area (that can be wet or dry during some periods of the year) and marginal lagoons (wet or dry) stand out as important environments for the maintenance of the hydrosedimentological dynamics of the river. 


\section{MATERIAL AND METHODS}

\subsection{STUDY AREA}

The São Francisco River watershed covers an area of eight federal units in Brazil: Minas Gerais, Bahia, Goiás, Pernambuco, Alagoas, Sergipe and the Distrito Federal (Brasília). Its drainage basin represents $8 \%$ of Brazilian territory with a drainage area of $634.000 \mathrm{~km}^{2}$. The São Francisco River has an extension of over $2.700 \mathrm{~km}$, with its springs located in Minas Gerais State (Canastra National Park) and the River mouth situated in the State of Alagoas. The River drains five states and 521 municipalities. It covers an area with middle to high hydric deficit and in many regions is the primary source of water for the local population. This extensive drainage basin is divided into four distinct zones (PATRUS et al., 2001):
A) the Upper São Francisco (from its spring till the city of Pirapora/Minas Gerais), B) The Middle São Francisco (Pirapora till the Sobradinho Lake in Bahia State), C) Sub medium São Francisco (Remanso till Paulo Afonso, both in Bahia State) and D) Low São Francisco (Paulo Afonso till the Atlantic Ocean in Alagoas State).

The study area belongs to the upper to middle São Francisco River basin, covering an area from its springs until Pirapora city, all located in Minas Gerais State (Figure 1). The climate of the region is classified (Köppen) as Aw, a typical raining tropical climate, with hot and humid summer months, and "dry" winter. The raining season with mean precipitation of $12 \mathrm{~mm}$ occurs from November until March.
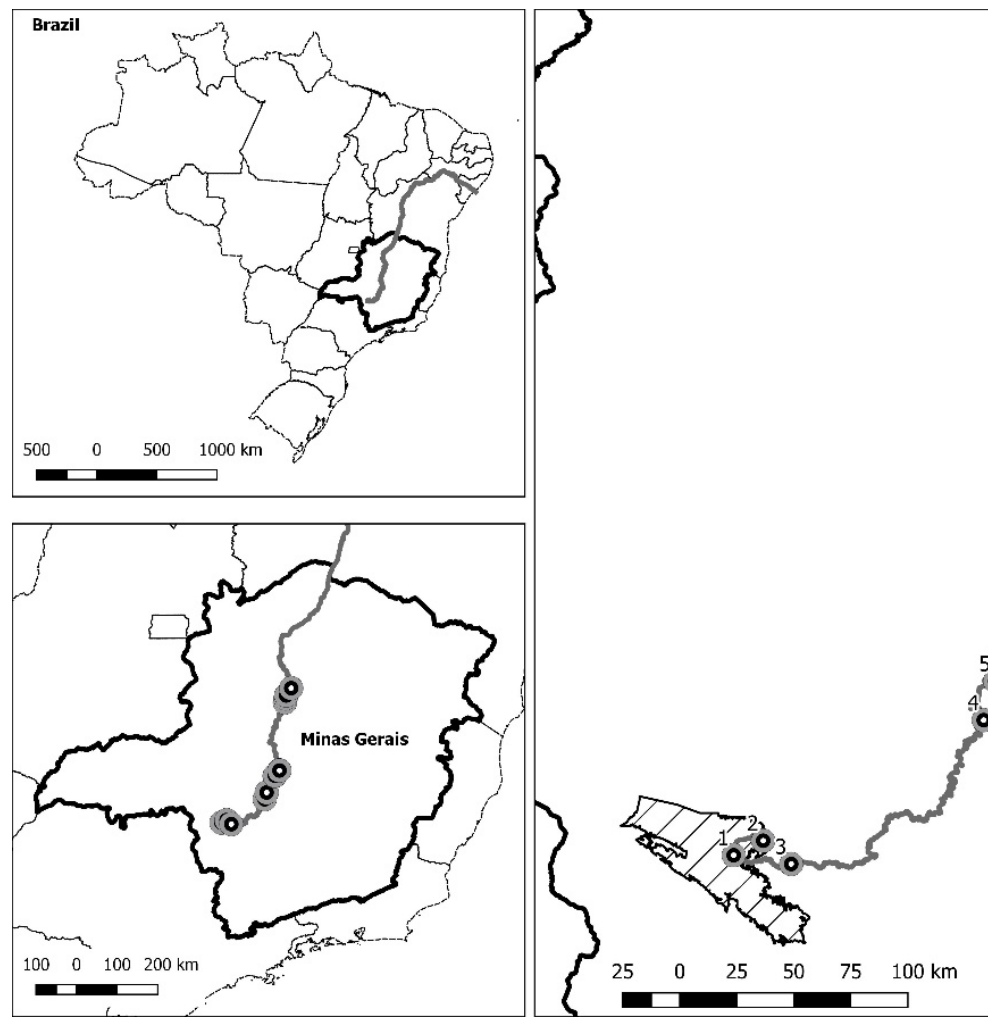

Map of São Francisco river and sampled sites.

Different compartments of the river were sampled: sediment from a pristine area right after de Canastra National Park; sediments in the margin of the river; sediments in wet inundation areas; sediments from marginal lagoons; soils from dry inundation area or dry marginal lagoons (Table 1). The main anthropic pressures are related to industrial and agricultural activities and house holding. Among the industrial activities, there are zinc processing, metallurgy (iron and 
silicon) and textile industries. The agricultural activities are diverse and range from small ranches until the production of corn, soy, cotton, coffee, eucalyptus, Pinus $s p$. and livestock and fish farms. There is also the disposal of domestic effluents without previous treatment in waters.

The sediments were sampled in February 2017 and April 2017. Fourteen sites were sampled since right after its springs till marginal lagoons in Pirapora City. Depending on the site, various samples were taken, in different areas or depths (Table 1). The samples were retrieved with a nonmetallic shovel, placed in plastic bags, kept on ice till its transport to the laboratory. In the laboratory, the samples were kept under $4^{\circ} \mathrm{C}$ till the beginning of the analyses.

Table 1 - Description of sampled sites (A: Sediments from marginal lagoons, B: Soils from inundation area or dry lagoons, C: Sediment from wet inundation areas, D: Sediment from pristine area of the river and E: Sediment from impacted areas of the river).

\begin{tabular}{|c|c|c|c|c|c|c|}
\hline ID & $\begin{array}{l}\text { Type of } \\
\text { Sampled } \\
\text { Site }\end{array}$ & Site & Place of sampling & $\begin{array}{c}\text { Sampling } \\
\text { depth }(\mathrm{cm})\end{array}$ & $\begin{array}{l}\text { Type of } \\
\text { Sample }\end{array}$ & Coordinates \\
\hline 1 & $\mathrm{D}$ & Pristine River & Margin of the river & $0-5$ & Sediment & $--46,5227 /-20,3082$ \\
\hline 2 & $E$ & Impacted River & Margin of the river & $0-5$ & Sediment & \\
\hline $2-1$ & $\mathrm{E}$ & Impacted River & Margin of the river & $5-10$ & Sediment & $-46,3982 /-20,2508$ \\
\hline 3 & $\mathrm{C}$ & Inundation Area & Wet & $0-5$ & Sediment & $-46,2801 /-20,3429$ \\
\hline 4 & $\mathrm{E}$ & Impacted River & Margin of the river & $0-5$ & Sediment & \\
\hline 4-1 & E & Impacted River & Margin of the river & $5-10$ & Sediment & $-45,4686 /-19,7738$ \\
\hline 5 & A & Gentil Farm/Lagoon & $1 \mathrm{~m}$ inside the lagoon & $0-5$ & Sediment & \\
\hline $5-1$ & A & Gentil Farm/Lagoon & $1 \mathrm{~m}$ inside the lagoon & $5-10$ & Sediment & $-45,4201 /-19,6191$ \\
\hline 6 & $\mathrm{~B}$ & Inundation Area & Dry & $0-5$ & Soil & $-45,2275 /-19,2394$ \\
\hline $6-1$ & $\mathrm{~B}$ & Inundation Area & Dry & $0-10$ & Soil & $-45,2193 /-19,2308$ \\
\hline 7 & $\mathrm{C}$ & Inundation Area & Wet & $0-5$ & Sediment & $-45,2193 /-19,2308$ \\
\hline 8 & $\mathrm{~B}$ & Riacho Farm & Dried Lagoon 1 & $0-5$ & Soil & \\
\hline $8-1$ & $\mathrm{~B}$ & Riacho Farm & Dried Lagoon 1 & $5-10$ & Soil & $-45,1075 /-17,5431$ \\
\hline 9 & B & Riacho Farm & Dried Lagoon 2 & $0-5$ & Soil & \\
\hline $9-1$ & $\mathrm{~B}$ & Riacho Farm & Dried Lagoon 2 & $5-10$ & Soil & $-45,1083 /-19,1116$ \\
\hline 10 & $\mathrm{~B}$ & Riacho Farm & Dried Lagoon 3 & $0-5$ & Soil & \\
\hline $10-1$ & $\mathrm{~B}$ & Riacho Farm & Dried Lagoon 3 & $5-10$ & Soil & $-45,109 /-19,11$ \\
\hline $11-1$ & A & Guim Lagoon & Inundation area & $0-5$ & Sediment & \multirow{4}{*}{$-44,9748 /-17,5431$} \\
\hline $11-2$ & A & Guim Lagoon & $1 \mathrm{~m}$ inside the lagoon & $0-5$ & Sediment & \\
\hline $11-3$ & A & Guim Lagoon & $5 \mathrm{~m}$ inside the laggon & $0-5$ & Sediment & \\
\hline $11-4$ & A & Guim Lagoon & Middle of the lagoon & $0-5$ & Sediment & \\
\hline $12-1$ & A & Atoleiro Lagoon & Inundation area & $0-5$ & Sediment & \multirow{4}{*}{$-44,9595 /-17,4497$} \\
\hline $12-2$ & A & Atoleiro Lagoon & $1 \mathrm{~m}$ inside the lagoon & $0-5$ & Sediment & \\
\hline $12-3$ & A & Atoleiro Lagoon & $5 \mathrm{~m}$ inside the laggon & $0-5$ & Sediment & \\
\hline $12-4$ & A & Atoleiro Lagoon & Middle of the lagoon & $0-5$ & Sediment & \\
\hline $13-1$ & $\mathrm{~A}$ & Pontal Lagoon & Inundation area & $0-5$ & Sediment & \multirow{4}{*}{$-44,9442 /-17,3806$} \\
\hline $13-2$ & A & Pontal Lagoon & $1 \mathrm{~m}$ inside the lagoon & $0-5$ & Sediment & \\
\hline $13-3$ & A & Pontal Lagoon & $5 \mathrm{~m}$ inside the laggon & $0-5$ & Sediment & \\
\hline $13-4$ & A & Pontal Lagoon & Middle of the lagoon & $0-5$ & Sediment & \\
\hline $14-1$ & A & Formoso Lagoon & Inundation area & $0-5$ & Sediment & \multirow{4}{*}{$-44,8218 /-17,2101$} \\
\hline $14-2$ & A & Formoso Lagoon & $1 \mathrm{~m}$ inside the lagoon & $0-5$ & Sediment & \\
\hline $14-3$ & A & Formoso Lagoon & $5 \mathrm{~m}$ inside the laggon & $0-5$ & Sediment & \\
\hline $14-4$ & A & Formoso Lagoon & Middle of the lagoon & $0-5$ & Sediment & \\
\hline
\end{tabular}

* Datum WGS1984: National Imagery and Mapping Agency, 1984 Department of Defense World Geodetic System, Its Definition and Relationships with Local Geodetic Systems. NIMA TR8350.2. 


\subsection{ANALYTICAL METHODS}

Sediments were oven dried at $30^{\circ} \mathrm{C}$ for 24 hours. Samples were grounded and passed through a $0.063 \mathrm{~mm}$ sieve. The fine sediment was subject to the Soxhlet extraction Method 3540c to extract organic pollutants (EPA 1996). Briefly, $20 \mathrm{~g}$ of dried sediment were extracted with $200 \mathrm{~mL}$ of Acetone/Hexane in a 1:1 proportion for 24 hours. The extracts presented a yellowish color related to the amount of the organic pollutants extracted. The extracts

\section{RESULTS AND DISCUSSION}

The organic matter content varied between $2.78 \%$ and $22.08 \%$ (Figure 2). Site 4 (margin of the river) and marginal lagoons (all sampled sites) were the ones with the highest organic matter content. The sediments presented organic matter content varying from low to medium quantities. Figure 3 shows the organic matter content in the sampling points, reflecting the distance from the spring. There was no correlation between these two variables.

The absorbance varied between $0.01 \%$ till $0.98 \%$. Again the site 4 at the margin of the river and the marginal lagoons were the ones to show the highest yellowish color (Figure 3). The measured absorbance indicates the presence of organic pollutants in the sediments of the different compartments of the São Francisco River. were measured in a spectrophotometer in the absorbance range of $589 \mathrm{~nm}$, which correspond to the yellow part of the visible spectrum, that corresponds to the extraction of the organic pollutants. The organic matter of the sediments was measured through the Loss on Ignition (LOI) method (JACKSON, 1958). The measured absorbance and the organic matter content were analyzed through a Pearson correlation analysis.

As said before, there are intense human activities in the São Francisco watershed. Among them industrial activities, agricultural activities and the discharge of domestic sewage. These activities can be the main source of organic pollutants as PCBs, PAH, organochlorine and organophosphorus pesticides. These compounds enter the aquatic environment due to seepage and runoffs (DUBUS et al., 2000). More than $90 \%$ of the presence of organic pollutants in the environment is directly related to accidents due to human failures and activities including deliberate waste disposal (ZHU et al., 2001). As seen for the organic matter content, there was no relationship between the distances from the spring with the presence of the organic compounds.

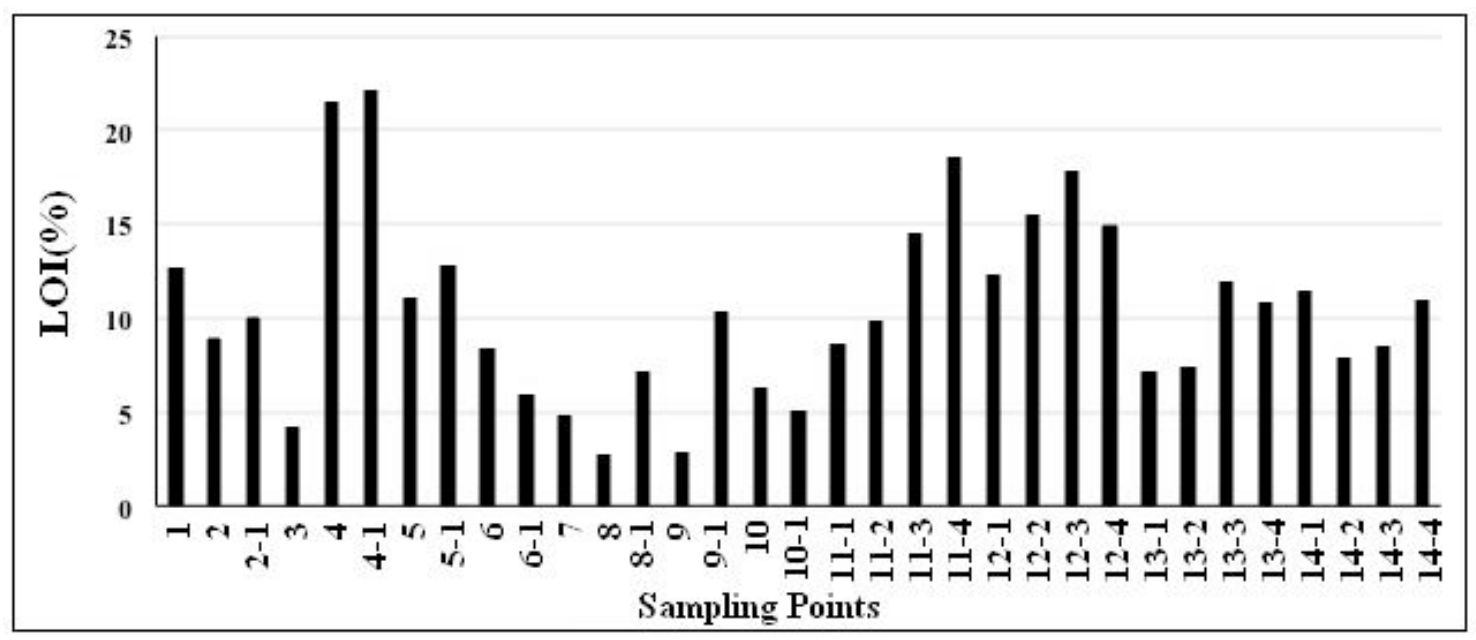

Figure 2

Organic matter content (LOI \%) in the sampled points in the São Francisco watershed. 


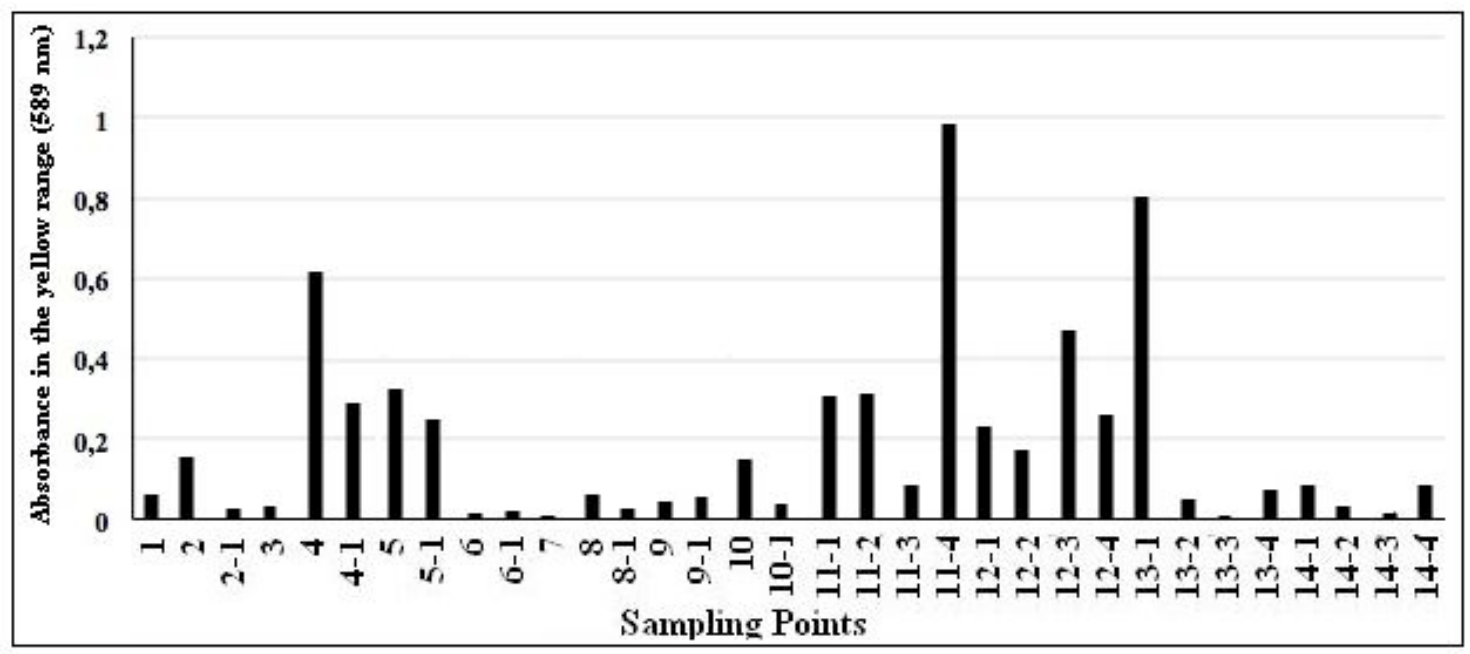

Figure 3

Absorbance in the yellowish color $(589 \mathrm{~nm})$ in the sampled points in the São Francisco watershed.

The Pearson Correlation analysis showed that there is a significant correlation between the organic matter content and the presence of organic pollutants $(0.53$, $p<0.05)$. There has been shown that organic matter can sequestrate organic pollutants, which will result in a correlation between organic matter content and presence of organic pollutants (CHUNG; ALEXANDER, 2002). The presence of these organic pollutants in the São Francisco river compartments is not surprising as these compounds are present around the world and in some developing countries the use of these compounds is still large due to their low cost, and versatility in industry and agriculture (TANABE et al., 1994). To understand the role of tropical developing countries as possible sources of organic pollutants is necessary to elucidate the distribution and fate of these compounds in various environmental compartments (ZHANG et al., 2003).

Organic pollutants are persistent in the environment, having long half-lives in soils and sediments, air and biota. They accumulate in the fat tissue of animals becoming a threat to the whole food chain (JONES; VOOGT, 1999). One of the main sources of organic pollutants is the application of pesticides in crops and soils (JONES; VOOGT, 1999). However, despite their deliberate manufacture, data on the total amount entering the environment and regional/global usage patters is highly uncertain and poorly understood (WANIA; MACKAY, 1996).

Even though it was not possible to determine which organic pollutants were present in the sediments of the different compartments of the São Francisco river, the results of this study clear indicates the presence of these compounds in the samples. The correlation of the organic matter content and the absorbance showed that the organic matter is an important mechanism in the sequestration of the organic pollutants (KILE et al., 1995). More studies should be conducted to determine which types of compounds are present in these sediments and if there is transfer of these organic pollutants in the aquatic food chain.

\section{ACKNOWLEDGEMENTS}

We thank CAPES for providing the PNPD post-doctorate scholarship for Dr. Torres. 


\section{REFERENCES}

BROWN, T. N.; WANIA, F. Screening chemicals for the potential to be persistent organic pollutants: a case study of Arctic contaminants. Environ Sci Technol, (42): 5202-5209, 2008

BUCCINI, J. The Development of a Global Treaty on Persistent Organic Pollutants (POPs). In: Fiedler H. (eds) Persistent Organic Pollutants. The Handbook of Environmental Chemistry (Vol. 3 Series: Anthropogenic Compounds), vol $3 \mathrm{O}$. Springer, Berlin, Heidelberg, 2003

CERNIGLIA, C. E. Biodegradation of polycyclic aromatic hydrocarbons. Biodegradation, (3): 351-368, 1992

CHUNG N.; ALEXANDER M. Effect of soil properties on bioavailability and extractability of phenanthrene and atrazine sequestered in soil. Chemosphere (48):109115,2002

DUBUS I. G.; HOLLIS J. M.; BROWN C. D. Pesticides in rainfall in Europe. Environ Pollut (110): 331-344, 2000

EPA Method 3540c - Soxhlet Extraction. Environmental Protection Agency, USA. 1996

GSCHWEND, P. M; WU, S. On the Constancy of Sediment-Water Partition Coefficients of Hydrophobic Organic Pollutants. Environ. Sci. Technol., (19): 90-96, 1985

HEITZER, A.; WEBB, O. F.; THONNARD, J. E.; SAYLER, G. S. Specifc and quantitative assessment of naphthalene and salicylate bioavailability by using a bioluminescent catabolic reporter bacterium. Applied and Environm. Microbiol. (58): 1839-1846, 1992

HONG, H.; XU L.; ZHANG J. C.; CHENT Y. S., WONG T.; WAN T. S. M. Environmental Fate and Chemistry of Organic Pollutants in the Sediment of Xiamen and Victoria Harbours Mar. Pollut. Bull. (31): 229-236, 1995

JACKSON, M.L. Soil Chemical Analysis. Prencite Hall, INC. Englewood Cliffs. NJ. 1958

JONES, K.C.; VOOGT P. Persistent organic pollutants (POPs): state of the science Environm. Poll. (100): 209-221, 1999

KILE, D. E.; CHIOU C. T.; ZHOU, H.; LI H.; $\mathrm{XU}$, O. Partition of Nonpolar Organic Pollutants from Water to Soil and Sediment Organic Matters. Environ. Sci. Technol. (29): 1401-1406, 1995

MEGHARAJ M.; RAMAKRISHNAN B.; VENKATESWARLU K.; SETHUNATHAN N.; NAIDU R. Bioremediation approaches for organic pollutants: A critical perspective Environm. Internat. (37): 1362-1375, 2011.

PARIATAMBY A.; KEE, L. Y. Persistent organic pollutants management and remediation. Procedia Environmental Sciences, 31, 842 - 848, 2016

PATRUS, M. L. R. A.; FIGUEIREDO, V. L. S.; MATOS, A. R.; SANTOS, A. C. S.; MENEZES, I. C. R.. Parcela Mineira da Bacia do São Francisco: Caracterização hidroclimática e avaliação dos Recursos Hídricos de Superfície. In Pinto, C.P.; Martins-Neto, M. (eds). Bacia do São Francisco: Geologia e recursos naturais. Belo Horizonte: SBG-MG, Cap. 6, 93-138, 2001

REID B. J.; JONES K. C.; SEMPLE K. T.; Bioavailability of persistent organic pollutants in soils and sediments-a perspective on mechanisms, consequences and assessment Environm. Poll. (108): 103112,2000

TANABE S.; IWATA H.; TATSUKAWA R. Global contamination by persistent organochlorines and their ecotoxicological impact on marine mammals. Sci. of the Total Environm. (154): 163-177, 1994

TANG, H. P. Recent development in analysis of persistent organic pollutants under the Stockholm Convention. Trends in Analytical Chemistry, (45): 48-66, 2013

WANIA, F.; MACKAY, D. Tracking the distribution of persistent organic pollutants. Environ. Sci. Technol. (30): 390-396, 1996

ZHANG, Z. L.; HONG, H. S.; ZHOU, J. L.; HUANG, J.; YU, G. Fate and assessment of persistent organic pollutants in water and sediment from Minjiang River Estuary, Southeast China. Chemosphere (52): 14231430, 2003

ZHU X, VENOSA AD, SUIDAN MT, LEE K. 2001. Guidelines for the bioremediation of marine shorelines and freshwater wetlands. Cincinnati, OH: US Environmental Protection Agency; http://www.epa.gov/oilspill/pdfs/bioremed.p df. 